\title{
Exercise, interleukins and bone homeostasis
}

\author{
John Kelly Smith* \\ Departments of Academic Affairs and Biomedical Sciences, East Tennessee State University, Tennessee, USA
}

\begin{abstract}
The proper balance between the production of osteoclastogenic and anti-osteoclastogenic interleukins by immune and bone cells is critical for the preservation of bone homeostasis and the maintenance of optimal bone mass. This article summarizes the mechanisms whereby interleukins with osteoclastogenic properties (interleukin$1 \beta$, interleukin 17A, interferon- $\gamma$, and tumor necrosis factor- $\alpha$ ) and anti-osteoclastogenic properties (interleukin-1 receptor antagonist, interleukin 4 , interleukin-6, interleukin-10, interleukin 13 , and transforming factor- $\beta$ ) effect the activities of osteoblasts, osteoclasts and osteocytes. It points out that long term moderate intensity aerobic exercise training can provide a cost-effective means for achieving a proper balance between immune cells producing osteoclastogenic and anti-osteoclastogenic interleukins.
\end{abstract}

\section{Introduction}

Interest in cytokines as regulators of bone metabolism began with the experiments of Horton and associates who, in 1972, found that conditioned medium from phytohemagglutinin (PHA)-stimulated peripheral blood mononuclear cells contained bone resorbing (osteoclastogenic) activity [1]. This activity was eventually found to be due to interleukin (IL)-1 and tumour necrosis factor (TNF)- $\alpha[2,3]$, prompting a series of studies examining the role of these and other proinflammatory cytokines as mediators of bone resorption in periodontal disease, rheumatoid arthritis, osteolytic malignancies, and osteoporosis [4-9]. In addition to IL- 1 and TNF- $\alpha$, the spectrum of cytokines with osteoclastogenic effects has expanded to include IL-17A [10]. In blood, these cytokines are variably produced by $\mathrm{T}$ helper type 1 (Th1) cells, natural killer (NK) cells, Th1-derived CD8+ T cells, Th17 cells, and M1polarized macrophages [11,12].

Subsequent studies have identified several interleukins whose activities inhibit bone resorption and/or promote bone formation (antiosteoclastogenic cytokines). These include IL-1 receptor antagonist (IL-1Ra), IL- 4, IL-10, IL-13 and transforming growth factor (TGF)- $\beta$ $[10,13]$. In blood, these cytokines are variably produced by Th2 cells, $\mathrm{T}$ and $\mathrm{B}$ regulatory cells, $\mathrm{T}$ follicular helper (TFH) cells, M2-polarized macrophages, and T2-derived CD8+ T cells [10-13].

There are several pleiotropic cytokines, interferon (IFN)- $\lambda$ and IL6 , whose effects on bone varies depending on experimental conditions; however, in most circumstances IL-6 is anti-osteoclastogenic whereas IFN- $\lambda$ is osteoclastogenic [14]. In blood, IFN- $\lambda$ is produced by Th 1 cells and M1-polarized macrophages, whereas IL- 6 is produced primarily by macrophages [10-13].

Immune cells occupying the microenvironment of bone are ideally situated to influence the ontogeny and functioning of cells responsible for bone formation (osteoblasts), bone resorption (osteoclasts) and the transduction of bone loading signals (osteocytes) [14].Osteoblasts and osteoclasts are derived from bone marrow stromal mononuclear cells, and retain the capacity to produce several cytokines, particularly IL-6 and TGF- $\beta$. Osteocytes are derived from osteoblasts as they age and become imbedded in the lacuno-canalicular network of bone [15].

\section{Mechanism of action}

Osteoclastogenic interleukins IL-1 $\alpha$ and TNF- $\alpha$ promote osteoclastogenesis by inducing osteoblasts to express receptor activator of nuclear factor kappa B (NFKB) ligand (RANKL) and bind to RANKL receptors (RANK) on stromal osteoclast precursors, or produce soluble RANKL to perform the same function $[5,8]$. TNF- $\alpha$ potently activates osteoclasts through a direct action independent of and strongly synergistic with RANKL [16]; it also inhibits bone formation in vitro [17]. IL- $1 \alpha$ and TNF- $\alpha$ exert potent anti-apoptotic effects on osteoclasts [10], and interact synergistically with one another [18] and with PTH [19] to enhance their bone resorptive capacities.

IL-17A induces RANKL expression in osteoblasts, promoting the differentiation of osteoclasts from their stromal mononuclear cell precursors. This cytokine has the capacity to activate macrophages to secrete IL- $1 \beta$ and TNF- $\alpha$, thereby indirectly upregulating osteoclastogenesis. In rodents, neutralization of IL-17A with polyclonal anti-17A antibody has been shown to downregulate bone erosion, RANKL expression, and the number of RANKL positive cells in inflamed joints [10].

IFN- $\lambda$ effects on bone metabolism varies depending on experimental conditions [20]. It inhibits RANKL- induced osteoclastogenesis by degrading the RANK adapter protein TRAF6 (tumor necrosis factor receptor-associated factor 6), a mechanism felt to protect against excessive. T cell-mediated bone resorption [21]. Recombinant IFN- $\lambda$ has also been shown to preferentially inhibit IL-1 and TNF-stimulated bone resorption in vitro [22], and to be osteoprotective when administered to ovariectomized mice [23]. In

Correspondence to: John Kelly Smith, Department of Academic Affairs, East Tennessee State University, Tennessee, USA, Tel: + 423-439-8005; E-mail: SMITHJ@mail.etsu.edu

Key words: interleukins, osteoclastogenesis, osteoblasts, osteoclasts, osteocytes, exercise, bone homeostasis

Received: October 10, 2016; Accepted: October 26, 2016; Published: October 28, 2016 
contrast, this cytokine has been shown to inhibit collagen synthesis in cultures of rat [24] and human bone cells [25], to cause bone loss when administered intra-peritoneally to experimental rats [26], and to demonstrate efficacy in the treatment of osteopetrosis $[27,28]$. IFN- $\lambda$ also promotes osteoclastogenesis indirectly by upregulating MHC class I and II expression on antigen presenting cells and by stimulating the release of TNF- $\alpha$ and RANKL by activated T cells [20]. The evidence suggests that under conditions of estrogen deficiency, infection, and/or inflammation, the net effect of IFN- $\lambda$ is biased toward bone resorption [20]. Of note is that under physiologic conditions secretion of this cytokine is strictly confined to sites of cell-to-cell interaction between immune cells where it is rapidly destroyed, and thus its potential to function in free form is limited.

The anti-osteoclastogenic interleukin IL1-Ra, by binding to type I and II IL-1 receptors, inhibits IL-1-mediated osteoclastogenesis [13].

IL-4 and IL-13 represses osteoclast development and function by a STAT6-dependent inhibition of RANKL [28]. They also upregulate osteoblast production of osteoprotegerin (OPG), a decoy RANKL receptor and potent inhibitor of osteoclastogenesis [29]. IL-4 has the potential to protect bone indirectly by promoting the differentiation of Th2 cells and M2-polarized macrophages and by inhibiting the differentiation of Th1 cells from activated CD4+ T cells; it also inhibits secretion of IL-1 $\beta$ and TNF- $\alpha$ by human monocytes [30]. IL-10 is a potent inhibitor of bone resorption.

It inhibits RANKL-mediated osteoclastogenesis by downregulating NFATc1 (nuclear factor of activated T cells) expression and nuclear translocation in mononuclear osteoclast precursors, and upregulates the expression of osteoprotegerin [31]. IL-10 protects bone indirectly by suppressing the secretion of osteoclastogenic cytokines in immune cells, most notably in activated M1-polarized macrophages [32]; it also inhibits lymphocyte production of IFN- $\lambda$ [33]. IL-10 deficient mice develop osteopenia, decreased bone formation, and mechanical fragility of long bones [34], attesting to the importance of its antiresorptive effects in vivo.

TGF- $\beta$ has pleiotropic effects on bone, which are predominantly osteogenic. By decreasing RANKL expression and enhancing OPG production in osteoblasts, this cytokine inhibits the proliferation, differentiation, and fusion of osteoclast precursors, inhibits osteoclast activity, and counteracts the resorptive activities of IL- 1 and TNF- $\alpha$ [35-38]. TGF- $\beta$ is a potent stimulator of bone formation, prompting osteoblast differentiation and synthesis of osteoid matrix and inhibiting the activity of osteoid degrading enzymes [38]; it also modulates osteoblast responses to osteotropic hormones, and serves as a chemotactic agent for cells of the osteoblast phenotype [35]. A latent form of TGF- $\beta$ is found in high concentrations in the matrix of calcified bone; when released in active form by the resorptive action of osteoclasts this cytokine is thought to help initiate the transition (coupling) phase of bone remodeling by stimulating osteoblast differentiation and recruitment and by suppressing osteoclastogenesis and osteoclast-mediated resorption [9,35-38]. Evidence suggests that TGF- $\beta$ couples bone resorption to bone formation by binding to receptors on osteoclasts and inducing the secretion of Wnt1, a protein crucial to normal bone formation [39]. TGF- $\beta$ can also protect bone indirectly by inhibiting the expression of proinflammatory cytokines and repressing IFN- $\lambda$ production by immune cells $[9,11]$.

IL-6 exerts context-dependent effects on bone metabolism $[5,40,41]$. Although it can stimulate osteoclastogenesis and bone resorption by upregulating RANKL expression in osteoblasts [42], its effects on bone metabolism are predominantly osteogenic and anti-resorptive. IL- 6 enhances bone formation by promoting the differentiation of osteoblast precursors $[43,44]$ and by protecting osteoblasts against apoptosis [5,45]; it can inhibit bone resorption directly by downregulating RANKL signaling pathways in osteoclasts [46] and indirectly by suppressing the production of TNF- $\alpha$ and IL- 1 and stimulating the production of IL-4, IL-10 and IL-1Ra by immune cells [47]. It is also an essential growth factor for B cells, the primary source of OPG in bone marrow stroma [48], and can induce IL-2 production in T cells [49]. IL-6 is produced in osteoblasts and osteocytes in response to bone loading signals, and, like TGF- $\beta$, plays an important role in bone remodelling [50,51].

\section{Effect of exercise}

In a clinical study involving 43 adult subjects, we found that 6 months of moderate intensity exercise decreased the spontaneous and PHA-induced production of osteoclastogenic cytokines (IL-1, TNF- $\alpha$, and IFN- $\gamma$ ) in cultured peripheral blood mononuclear cells (PBMCs) by $24 \%$ and $59 \%$, respectively. In contrast, the exercise training program increased the spontaneous and PHA-induced production of anti-osteoclastogenic cytokines (IL-4, IL-6, IL-10, and TGF- $\beta$ ) by $89 \%$ and $50 \%$, respectively. This change was accompanied by a $16 \%$ reduction in plasma levels of C-terminal telopeptides of Type I collagen, a reliable marker of bone resorption, and an $9.8 \%$ increase in plasma levels of osteocalcin, a reliable marker of bone formation. The reduction in bone resorption was proportionate to the time subjects spent in each training session doing aerobic exercises (75 minutes on average) [14]. Thus, one of the mechanisms whereby sustained exercise training enhances bone health is by favourably changing the balance between PBMCs producing osteoclastogenic and anti-osteoclastogenic cytokines. The mechanism(s) responsible for these changes is currently under investigation.

\section{Conclusion}

The proper balance between the production of osteoclastogenic and anti-osteoclastogenic interleukins by immune and bone cells is critical for the preservation of bone homeostasis and the maintenance of optimal bone mass. Long term moderate intensity aerobic exercise training provides a cost-effective means for achieving this balance.

\section{References}

1. Horton JE, Raisz LG, Simmons HA, Oppenheim JJ, Mergenhagen SE (1972) Bone resorbing activity in supernatant fluid from cultured human peripheral blood leukocytes. Science 177: 793-795. [Crossref].

2. Dewhirst FE, Stashenko PP, Mole JE, Tsurumachi T (1985) Purification and partial sequence of human osteoclast-activating factor: identity with interleukin 1 beta. $J$ Immunol 135: 2562-2568. [Crossref]

3. Pfeilschifter J, Chenu C, Bird A, Mundy GR, Roodman GD (1989) Interleukin-1 and tumor necrosis factor stimulate the formation of human osteoclastlike cells in vitro. $J$ Bone Miner Res 4: 113-118. [Crossref]

4. Ralston SH (1992) Role of cytokines in clinical disorders of bone metabolism. In Cytokines and Bone Metabolism. M Gowen ed. CRC Press, Inc., London; 361-381.

5. Steeve KT, Mare P, Sandrine T, Dominique H, Yannick F (2004) IL-6, RANKL, TNFalpha/IL-1 interrelations in bone resorption pathophysiology. Cytokine Growth Factor Rev 15: 49-60.

6. Mori G, D'Amelio P, Faccio R, Brunetti G (2015) Bone-immune cell crosstalk: bone diseases. J Immunol Res 2015: 108451. [Crossref]

7. Weitzmann MN, Pacifici R (2005) Role of the immune system in postmenopausal bone loss. Curr Osteoporos Rep 3: 92-97. [Crossref]

8. Wada T, Nakashima T, Hiroshi N, Penninger JM (2006) RANKL-RANK signaling in osteoclastogenesis and bone disease. Trends Mol Med 12: 17-25. [Crossref] 
9. Zupan J, Jeras M, Marc J (2013) Osteoimmunology and the influence of proinflammatory cytokines on osteoclasts. Biochem Med (Zagreb) 23: 43-63. [Crossref]

10. Adamopoulos IE, Bowman EP (2008) Immune regulation of bone loss by Th17 cells. Arthritis Res Ther 10: 225. [Crossref]

11. Weitzmann MN, Pacifici R (2005) The role of T lymphocytes in bone metabolism. Immunol Rev 208: 154-168. [Crossref]

12. KR Murphy, ed., Janeways Immunobiology, 8th edition. Garland Science, Taylor \& Francis Group, LLC, New York. 2012.

13. Akdis M, Burgler S, Crameri R, Eiwegger T, Fujita H, et al. (2011) Interleukins, from 1 to 37 , and interferon- $\hat{I}^{3}$ : receptors, functions, and roles in diseases. J Allergy Clin Immunol 127: 701-721. [Crossref]

14. Smith JK, Dykes R, Chi DS (2016) The Effect of Long-Term Exercise on the Production of Osteoclastogenic and Antiosteoclastogenic Cytokines by Peripheral Blood Mononuclear Cells and on Serum Markers of Bone Metabolism. J Osteoporos 2016: 5925380. [Crossref]

15. Xiao W, Wang Y, Pacios S, Li S, Graves DT (2016) Cellular and Molecular Aspects of Bone Remodeling. Front Oral Biol 18: 9-16. [Crossref]

16. Fuller K, Murphy C, Firstein B, Fox SW, Chambers TJ (2002) TNF alpha potently activates osteoclasts, through a direct action independent and strongly synergistic with RANKL. Endocrinol 143: 1108-1118.

17. Bertolini DR, Nedwin GE, Bringman TS, Smith DD, Mundy GR (1986) Stimulation of bone resorption and inhibition of bone formation in vitro by human tumour necrosis factors. Nature 319: 516-518. [Crossref]

18. Stashenko P, Dewhirst FE, Peros WJ, Kent RL, Ago JM (1987) Synergistic interactions between interleukin-1, tumor necrosis factor, and lymphotoxin in bone resorption. J immunol 138: 1464-1468. [Crossref]

19. Dewhirst FE, Ago JM, Peros WJ, Stashenko P (1987) Synergism between parathyroid hormone and interleukin 1 in stimulating bone resorption in organ culture. $\mathrm{J}$ Bone Miner Res 2: 127-134. [Crossref]

20. Gao Y, Grassi F, Ryan MR, Terauchi M, Page K, et al. (2007) IFN-gamma stimulates osteoclast formation and bone loss in vivo via antigen-driven $\mathrm{T}$ cell activation. $J$ Clin Invest 117: 122-132. [Crossref]

21. Takayanagi H, Ogasawara K, Hida S, Chiba T, Murata S, et al. (2000) T-cell-mediated regulation of osteoclastogenesis by signalling cross-talk between RANKL and IFNgamma. Nature 408: 600-605. [Crossref]

22. Gowen M, Nedwin GE, Mundy GR (1986) Preferential inhibition of cytokinestimulated bone resorption by recombinant interferon gamma. $J$ Bone Miner Res 1: 469-474.

23. Duque G, Huang DC, Dion N, Macoritto M, Rivas D, et al. (2011) Interferon- $\hat{I}^{3}$ plays a role in bone formation in vivo and rescues osteoporosis in ovariectomized mice. $J$ Bone Miner Res 26: 1472-1483. [Crossref]

24. Smith DD, Gowen M, Mundy GR (1987) Effects of interferon-gamma and other cytokines on collagen synthesis in fetal rat bone cultures. Endocrinology 120: 24942499. [Crossref]

25. Beresford JN, Taylor GT, Triffitt JT (1990) Interferons and bone. A comparison of the effects of interferon-alpha and interferon-gamma in cultures of human bone-derived cells and an osteosarcoma cell line. Eur J Biochem 193: 589-597. [Crossref]

26. Mann GN, Jacobs TW, Buchinsky FJ, Armstrong EC, Li M, et al. (1994) Interferongamma causes loss of bone volume in vivo and fails to ameliorate cyclosporin A-induced osteopenia. Endocrinology 135: 1077-1083. [Crossref]

27. Key LL Jr, Rodriguiz RM, Willi SM, Wright NM, Hatcher HC, et al. (1995) Long-term treatment of osteopetrosis with recombinant human interferon gamma. $N$ Engl J Med 332: 1594-1599. [Crossref]

28. Moreno JL, Kaczmarek M, Keegan AD, Tondravi M (2003) IL-4 represses osteoclast development and mature osteoclast function by a STAT6-dependent mechanism: irreversible inhibition of the differentiation program activated by RANKL. Blood 102: 1078-1086. [Crossref]

29. Yamada A, Takami M, Kawawa T, Yasuhara R, Zhao B, Mochizuki A, et al. (2007) Interleukin-4 inhibition of osteoclast differentiation is stronger than that of interleukin-13 and they are equivalent for induction of osteoprotegerin production from osteoblasts. Immunol 120: 573-579. [crosssref]

30. Te Velde AA, Huijbens RJ, Heije K, de Vries JE, Figdor CG (1990) Interleukin-4 (IL-4) inhibits secretion of IL-1 beta, tumor necrosis factor alpha, and IL-6 by human monocytes. Blood 76: 1392-1397. [Crossref]
31. Evans KE, Fox SW (2007) Interleukin-10 inhibits osteoclastogenesis by reducing NFATc1 expression and preventing its translocation to the nucleus. BMC Cell Biol 8: 4. [Crossref]

32. Fiorentino DF, Zlotnik A, Mosmann TR, Howard M, O Garra A (1991) IL-10 inhibits cytokine production by activated macrophages. J Immunol 147: 3815-3822. [Crossref]

33. D'Andrea A, Aste-Amezaga M, Vaiante NM, Ma X, Kubin M, et al. (1993) Interleukin 10 (IL-10) inhibits human lymphocyte interferon-? production by suppressing natural killer cell stimulatory factor/IL-12 synthesis in accessory cells. J Exp Med 178: 10411048. [Crossref]

34. Dresner-Pollak R, Gelb N, Rachmilewitz D, Karmeli F, Weinreb M (2004) Interleukin 10-deficient mice develop osteopenia, decreased bone formation, and mechanical fragility of long bones. Gastroenterol 127: 792-801. [Crossref]

35. Mundy GR, Bonewald LF. Transforming growth factor beta. In Cytokines and bone metabolism. Gowen M ed. CRC Press, Inc, London, 1992, pp 94-107.

36. Quinn JM, Itoh K, Udagawa N, Hausler K, Yasuda H, et al. (2001) Transforming growth factor beta affects osteoclast differentiation via direct and indirect actions. $J$ Bone Miner Res 16: 1787-1794. [Crossref]

37. Schwartz Z, Olivares-Navarrete R, Wieland M, Cochran DL, Boyan BD (2009) Mechanisms regulating increased production of osteoprotegerin by osteoblasts cultured on microstructured titanium surfaces. Biomaterials 30: 3390-3396. [Crossref]

38. Kini U, Nandeesh BN (2012) Physiology of Bone Formation, Remodeling, and Metabolism. Radionucleotide and Hybrid Bone Imaging 3: 29-57

39. Weivoda MM, Ruan M, Pederson L, Hachfeld C, Davey RA, et al. (2016) Osteoclas TGF-I $\hat{I}^{2}$ Receptor Signaling Induces Wnt1 Secretion and Couples Bone Resorption to Bone Formation. J Bone Miner Res 31: 76-85. [Crossref]

40. Blanchard F, Duplomb L, Baud'huin M, Brounais B (2009) The dual role of IL-6-type cytokines on bone remodeling and bone tumors. Cytokine Growth Factor Rev 20: 1928. [Crossref]

41. Franchimont N, Wertz S, Malaise M (2005) Interleukin-6: An osteotropic factor influencing bone formation. Bone 37: 601-606. [Crossref]

42. Palmqvist P, Persson E, Conaway HH, Lerner UH (2002) IL-6, leukemia inhibitory factor, and oncostatin $\mathrm{M}$ stimulate bone resorption and regulate the expression of receptor activator of NF-kappa B ligand, osteoprotegerin, and receptor activator of NFkappa B in mouse calvariae. J Immunol 169: 3353-3362. [Crossref]

43. Erices A, Conget P, Rojas C, Minguell JJ (2002) GP130 activation by soluble interleukin-6 receptor/interleukin-6 enhances osteoblastic differentiation of human bone marrow-derived mesenchymal stem cells. Exp Cell Res 280: 24-32. [Crossref]

44. Itoh S, Udagawa N, Takahashi N, Yoshitake F, Narita H, et al. (2006) A critical role for interleukin-6 family-mediated Stat 3 activation in osteoblast differentiation and bone formation. Bone 39: 505-512. [Crossref]

45. Jilka RL, Weinstein RS, Bellido T, Parfitt AM, Manolagas SC (1998) Osteoblas programmed cell death (apoptosis): modulation by growth factors and cytokines. $J$ Bone Miner Res 13: 793-802. [Crossref]

46. Yoshitake F, Itoh S, Narita H, Ishihara K, Ebisu S (2008) Interleukin-6 directly inhibits osteoclast differentiation by suppressing receptor activator of NF-kappaB signaling pathways. J Biol Chem 283: 11535-11540. [Crossref]

47. Petersen AM, Pedersen BK (2006) The role of IL-6 in mediating the anti-inflammatory effects of exercise. J Physiol Pharmacol 57 Suppl 10: 43-51. [Crossref]

48. Li Y, Toraldo G, Li A, Yang X, Zhang H, et al. (2007) B cells and T cells are critical for the preservation of bone homeostasis and attainment of peak bone mass in vivo. Blood 109: 3839-3848. [Crossref]

49. Löwik CWGM. Differentiation inducing factors: leukemia inhibitory factor and interleukin-6. In Cytokines and Bone Metabolism, M Gowen ed, CRC Press Inc, London. 1992, pp 299-324.

50. Fukuno N, Matsui H, Kanda Y, Suzuki O, Matsumoto K, Sasaki K, et al. (2011) TGF-ß activated kinase 1 mediates mechanical stress-induced IL-6 expression in osteoblasts. Biochem Biophys Res Comm 408: 202-207. [Crossref]

51. Bakker AD, Kulkarni RN, Klein-Nulend J, Lems WF (2014) IL-6 alters osteocyte signaling toward osteoblasts but not osteoclasts. J Dent Res 93: 394-399. [Crossref]

Copyright: (C2016 Smith JK. This is an open-access article distributed under the terms of the Creative Commons Attribution License, which permits unrestricted use, distribution, and reproduction in any medium, provided the original author and source are credited. 